\title{
Reptilase Time Measurement
}

National Cancer Institute

\section{Source}

National Cancer Institute. Reptilase Time Measurement. NCI Thesaurus. Code $C 96628$.

A measurement of the time it takes a plasma sample to clot after adding the snake venom enzyme batroxobin (reptilase). This procedure can be used to detect deficiencies or abnormalities in fibrinogen and this enzyme is resistant to both endogenous thrombin inhibitors and heparin. 